\title{
Wojciech Sokół
}

\section{Pojęcie, specyfika i uwarunkowania partii władzy w Federacji Rosyjskiej}

K ategoria „partie władzy” jest często używana przez politologów w kontekście charakterystyki systemu politycznego i partyjnego Federacji Rosyjskiej. Refleksje na temat istoty, cech i uwarunkowań funkcjonowania partii władzy są podejmowane w literaturze polskiej i zagranicznej ${ }^{1}$. Podkreślana jest również nieprzystawalność rosyjskich partii politycznych (w tym partii władzy) i systemu partyjnego do partii politycznych i systemów partyjnych demokracji zachodnich zarówno w wymiarze funkcjonalnym, jak i w sferze myśli politycznej ${ }^{2}$. Wielu autorów wyraża również przekonanie o uzależnieniu partii władzy w Rosji od ośrodka prezydenckiego ${ }^{3}$. Celem poniższego opracowania jest omówienie i analiza partii władzy w Rosji oraz zweryfikowanie tez postawionych $\mathrm{w}$ artykule.

1 Zob. szerzej: R. Bäcker, Rosyjskie myślenie polityczne za czasów prezydenta Putina, Toruń 2007, s. 42-45 czy J. Potulski, System partyjny Rosji. Tradycja i współczesność, Gdańsk 2007, s. 267; J. Potulski, Rola i znaczenie tradycji w funkcjonowaniu wspótczesnych instytucji politycznych w Rosji, Toruń 2005, passim; A. Stelmach, Zmiana i stabilność w systemie politycznym wspótczesnej Rosji, Poznań 2003, passim; E. Zieliński, Współczesna Rosja: studium polityczno-ustrojowe, Warszawa 1995, passim; A. Czajowski, Demokratyzacja Rosji w latach 1987-1999, Wrocław 2001, passim; W. Marciniak, Rozgrabione imperium: upadek Związku Sowieckiego i powstanie Federacji Rosyjskiej, Kraków 2004, passim; Rozpad ZSRR i jego konsekwencje dla Europy i świata, red. A. Jach, Kraków 2011, passim; Federacja Rosyjska, 1991-2001, red. J. Adamowski, J. Skrzypek, Warszawa 2002, passim; O. Krysztanowskaja, Anatomia rossijskoj elity, Moskwa 2004, passim; W. Sorgin, Politiczeskaja istoria sowriemiennoj Rossiji, 1985 2001: od Gorbaczewa do Putina, Moskwa 2001, s. 201-235; Rosja. Współczesny system polityczny, red. J. I. Matwijenko, M. Wilk, Łódź 2008, s. 84-122; K. Świder, Ewolucja elity władzy w Zwiazku Radzieckim i Rosji, Warszawa 2013, s. 239-320; J. Jendrysko, Rola Jednej Rosji na rosyjskiej scenie politycznej, „Studia Politicae Universitatis Silesiesiensis" 2016, t. 17, s. 140-156; M. Słowikowski, Jedna Rosja w systemie politycznym Federacji Rosyjskiej, Łódź 2018, s. 58-69.

2 A.R. Bartnicki, Demokratycznie legitymizowany autorytaryzm w Rosji 1991-2004, Białystok 2007, s. 191.

3 Zob. np. R. Bäcker, op. cit., s. 44 czy J. Potulski, System partyjny Rosji..., s. 267-268. 
Przedmiotem zainteresowania będą partie i bloki polityczne, które po 1991 roku były uznawane za partie władzy: Wybór Rosji, Nasz Dom - Rosja, Ojczyzna - Cała Rosja, Jedność oraz Jedna Rosja.

$\mathrm{W}$ artykule wykorzystano metody badawcze wypracowane w ramach teorii partii politycznych (m.in. elementy analizy systemowej, historycznej, instytucjonalno-prawnej) oraz technikę analizy treści literatury przedmiotu ${ }^{4}$.

\section{Dyskusje wokół pojęcia „partia władzy”}

W literaturze politologicznej pojawiło się dotychczas kilka prób zdefiniowania pojęcia „partia władzy”. Według Andrzeja Czajowskiego, partie władzy to „te ugrupowania, które były tworzone jako zaplecze polityczno-organizacyjne prezydenta lub rządu, lub te, które taką funkcję spełniały"s. Wydaje się jednak, że konstatacja o pełnieniu przez partie władzy funkcji zaplecza prezydenta i rządu nie do końca przybliża istotę partii władzy, ponieważ w każdym państwie demokratycznym partie rządzące pełnią podobną rolę wobec rządu.

Z kolei Jarosław Ćwiek-Karpowicz - a za nim Roman Bäcker - podzielili partie władzy na dwie kategorie: partie władzy pierwszego typu i partie władzy drugiego typu. J. Ćwiek-Karpowicz przez partię władzy pierwszego typu rozumie ugrupowania polityczne oficjalnie reprezentujące linię prezydenta, a według R. Bäckera partia władzy pierwszego typu to „taka struktura polityczna, która sprawuje władzę, a dokładniej: obsadza stanowiska w aparacie wykonawczym oraz popiera władcę, czyli współcześnie - prezydenta”. Badacz ten podkreślił także, że podstawowym celem partii władzy „nie jest [...] reprezentacja elektoratu, ale służba najwyższemu ośrodkowi władzy”. Należy zauważyć, że powyższa definicja akcentująca zależność rosyjskich partii władzy od ośrodka prezydenckiego także nie jest w pełni satysfakcjonująca, ponieważ sprawowanie władzy wykonawczej jest charakterystyczne dla każdej partii politycznej, która zwycięży w rywalizacyjnych wyborach. Z kolei za partię władzy drugiego typu R. Bäcker uznał organizację, której zadaniem jest „zagospodarowanie poparcia tych grup społecznych, które z różnych powodów nie popierają władzy, ale też nie są na tyle świadome, by odróżnić prawdziwą partię opozycyjną od partii władzy drugiego typu". Do cech charakterystycznych partii władzy drugiego typu zdaniem tego autora należą więc „wysuwanie opozycyjnych haseł programowych oraz praktyka popierania Kremla przy kluczowych głosowaniach w Dumie" . Definicja ta znacznie bardziej odpowiada pojęciu tzw. opozycji władzy, czyli ugrupowań formalnie niepartycypujących w układach rządzących, w okresach kampanii wyborczych stosujących nawet narrację kontestacji, ale w późniejszym czasie, zwłaszcza na forum Dumy Państwowej, zachowujących się w sposób pożądany przez rządzących.

4 Po powstaniu tego tekstu ukazała się obszerna monografia Michała Słowikowskiego na temat Jednej Rosji. Zob. szerzej: M. Słowikowski, op. cit., passim.

5 A. Czajowski, op. cit., Wrocław 2001, s. 207.

6 J. Ćwiek-Karpowicz, Rosyjska wielopartyjność w latach 1993-2003 - ewolucja systemu, „Międzynarodowy Przegląd Polityczny” 2004, nr 3/4, s. 49-51; R. Bäcker, op. cit., s. 44.

7 R. Bäcker, op. cit., s. 45. 
Bardziej rozbudowaną definicję zaproponował Jakub Potulski, który zdefiniował partie władzy w sposób sensu stricto i sensu largo. Partie władzy w znaczeniu wąskim (na poziomie federalnym) scharakteryzował jako „umowne określenie różnorodnych ugrupowań politycznych, które pojawiały się w parlamencie od 1993 r., wspierając politykę prezydenta i rządu”". Jest to definicja bliźniaczo podobna do tej zaproponowanej przez A. Czajowskiego, więc do koncepcji Potulskiego można odnieść te same uwagi, które dotyczyły pierwszej z przytoczonych definicji. Natomiast partie władzy w znaczeniu szerszym to według tego politologa „umowne określenie zwycięskiego konglomeratu wyborczego", przy czym „członkowie takich ugrupowań zazwyczaj rekrutują się z ludzi piastujących wysokie stanowiska w strukturach władzy wykonawczej i administracji prezydenckiej oraz spośród prowincjonalnych liderów politycznych. Są to osoby bardzo mocno związane z procesami dystrybucji władzy" ". W myśl tej koncepcji, oprócz struktur partyjnych w skład owego „konglomeratu” - czyli partii władzy - mają wchodzić państwowe struktury federalne egzekutywy i elity regionalne, a także struktury partyjne „zasadniczo popierające władzę, lecz w większej czy mniejszej mierze dystansujące się od niej". Zaletą takiego ujęcia problemu jest zaakcentowanie powiązań partii władzy z aparatem biurokratycznym Rosji i podkreślenie „odgórnego” charakteru powstawania tych ugrupowań, czyli tworzenia ich z inicjatywy przedstawicieli istniejącego już establishmentu. Wątpliwości może budzić natomiast nieostrość użytych sformułowań oraz brak wyraźnego odróżnienia partii władzy od struktur federalnych władzy wykonawczej i elit regionalnych.

Najbardziej lapidarna jest definicja Bożeny Pietrzko, która stwierdziła, że partie władzy to „ci, którzy posiadają faktyczną władzę w Rosji - elity polityczne, lobby finansowo-gospodarcze"10. Wydaje się, że takie ujęcie problemu utożsamia partię władzy z elitami politycznymi i finansowo-gospodarczymi Rosji, co czyniłoby z partii władzy grupę nieformalną. Takie uproszczenie w żaden sposób nie przybliża jednak do zrozumienia zjawiska partii władzy. Sprecyzowania wymaga również określenie posiadania „faktycznej władzy w Rosji”.

Wspólnym mianownikiem powyższych prób określenia pojęcia „partia władzy” było przekonanie o uzależnieniu takich ugrupowań politycznych od funkcjonującego w danym czasie ośrodka prezydenckiego - w latach 90. XX wieku w nauce funkcjonowało określenie „partia prezydencka”, używane jako synonim partii władzy ${ }^{11}$. Takie twierdzenie znajdowało uzasadnienie w czasie prezydentury Borysa Jelcyna i pierwszej prezydentury Władimira Putina ${ }^{12}$, ponieważ otoczenie Jelcyna i Putina rzeczywiście

8 J. Potulski, System partyjny Rosji..., s. 269.

9 Ibidem, s. 268.

10 B. Pietrzko, Geneza i konstytucyjna pozycja urzędu prezydenta jako elementy transformacji ustrojowej $w$ Rosji, [w:] Społeczeństwo wobec problemów transformacji i integracji, red. J. Liszka, Ustroń 2000, s. 283.

11 A. Czajowski, op. cit., s. 207.

12 Mianem „pierwszej prezydentury Władimira Putina” w niniejszym artykule określano lata 2000-2008, czyli pierwsze dwie kadencje Putina jako głowy państwa. Po raz kolejny Putin został 
tworzyło na ich potrzeby nowe ugrupowania polityczne. Zwłaszcza losy partii władzy kreowanych na potrzeby Jelcyna (Wybór Rosji i Nasz Dom - Rosja) mogły sugerować, że ich relewancja zależała od poparcia ośrodka prezydenckiego, a wraz ze zmianą na stanowisku głowy państwa partia władzy odejdzie w polityczny niebyt. Jednak wraz z końcem drugiej kadencji Putina konieczna była zmiana prezydenta, wynikająca z Konstytucji Federacji Rosyjskiej, która zakazuje tej samej osobie sprawowania funkcji prezydenta dłużej niż dwie kolejne kadencje ${ }^{13}$. W związku z koniecznością zmiany personalnej na stanowisku głowy państwa powstała wcześniej na potrzeby Putina partia Jedna Rosja wzięła udział - przynajmniej formalny -w procesie wyłaniania nowego kandydata na urząd głowy państwa, co nie było udziałem poprzednich partii władzy. Powyższa sytuacja niewątpliwie modyfikuje wcześniejsze próby zdefiniowania istoty partii władzy.

Wraz z objęciem stanowiska Prezydenta Federacji Rosyjskiej przez Dmitrija Miedwiediewa ujawniło się jeszcze jedno nowe zjawisko związane $\mathrm{z}$ funkcjonowaniem partii władzy. Do 2008 roku partie władzy - jak już wspomniano - traciły znaczenie wraz ze zmianą na stanowisku prezydenta. Tymczasem w czasie prezydentury Miedwiediewa w latach 2008-2012 Jedna Rosja nie przestała być partią władzy. Ugrupowanie to było więc pierwszą partią władzy, która zachowała swoje znaczenie pomimo zmiany na stanowisku prezydenta, przy czym nie zawdzięczała tego osobowości Miedwiediewa, tylko popularności Putina, który de facto desygnował go na swojego następcę ${ }^{14}$. Przykład Jednej Rosji pokazuje, że znaczenie polityczne partii władzy nie musi być ściśle uzależnione od osoby sprawującej urząd prezydencki, co automatycznie zakładały wcześniejsze ujęcia tego problemu.

Powyższe refleksje prowadzą do konkluzji, że przez partię władzy można rozumieć blok wyborczy lub ugrupowanie polityczne powstałe na potrzeby lidera politycznego lub grupy osób powiązanych z funkcjonującym aparatem państwowym, którego nadrzędnym celem jest zapewnienie poparcia parlamentarnego swoim mocodawcom lub osobom z ich najbliższego otoczenia. Taka definicja akcentuje „odgórne” tworzenie partii władzy przez konkretnych patronów tych partii, nie ograniczając jednak tych patronów do urzędujących prezydentów, a także precyzuje cel nadrzędny takich ugrupowań bez sprowadzania sensu istnienia tych ugrupowań jedynie do służby ośrodkowi prezydenckiemu ${ }^{15}$.

\section{Cechy charakterystyczne partii władzy w Rosji}

Poza rozważaniami definicyjnymi w literaturze politologicznej przedmiotem refleksji są także cechy charakterystyczne partii władzy. Wskazuje się, że kluczowym czynnikiem wyróżniającym partie władzy od innych ugrupowań politycznych jest wspomniany już

prezydentem w roku 2012 oraz 2018, tym razem na kadencję sześciu lat. Zob. szerzej: K. Świder, op. cit., s. 274-286.

13 Art. 81 ust. 3 Konstytucji Federacji Rosyjskiej z 12 grudnia 1993 r. (dalej: Konstytucji).

14 J. Rogoża, Wybory prezydenckie w Rosji i ich konsekwencje dla Rosji oraz otoczenia międzynarodowego, „Komentarze OSW” 2008, nr 1, s. 2.

15 Powyższe ujęcie jest zbieżne z ujęciem Olgi Krysztanowskiej: O. Krysztanowskaja, op. cit., s. 85. 
charakter powstawania tych partii, które zostały wykreowane na potrzeby poszczególnych liderów politycznych, w których tworzeniu brały udział grupy osób powiązanych z aparatem państwowym. Do tworzenia rosyjskich partii władzy przyczyniali się - oprócz kluczowych aktorów rosyjskiej sceny politycznej - m.in. czołowi przedstawiciele elit regionalnych (głównie merowie i gubernatorzy), oligarchowie (np. Borys Berezowski) i dyrektorzy kluczowych przedsiębiorstw (przede wszystkim Gazpromu) ${ }^{16}$.

Należy się zgodzić z R. Bäckerem, że jedną z najważniejszych cech partii władzy jest specyficzny cel jej działania, za który uważa on służbę najwyższemu ośrodkowi władzy, a nie reprezentację elektoratu. Zdaniem R. Bäckera świadczyć o tym może enigmatyczność programów wyborczych partii władzy ${ }^{17}$. Faktycznie w dokumentach programowych partii władzy bez trudu można odnaleźć dość mgliście omówione hasła. I tak, w programie wyborczym Jednej Rosji z 2011 r. trudno znaleźć propozycje konkretnych rozwiązań, ale dokument ten pełen jest niewiele mówiących postulatów, takich jak „modernizacja gospodarki”, „spełnienie zobowiązań socjalnych” czy „podtrzymanie międzynarodowego i międzywyznaniowego pokoju"18. Jednak tego typu rozwiązania charakteryzują większość współczesnych partii politycznych typu catch-all i mają za zadanie raczej przyciągnięcie różnych segmentów elektoratu niż zniechęcanie jakiejś jego części kontrowersyjnymi elementami programu ${ }^{19}$. Nie jest to zatem oryginalny pomysł rosyjskich partii władzy, choć niewątpliwie cytowany autor ma rację, gdy twierdzi, że funkcja artykulacji i agregacji potrzeb i interesów społecznych w przypadku rosyjskich partii władzy schodzi na drugi plan, ustępując miejsca służbie najwyższemu ośrodkowi władzy, przy wspomnianym zastrzeżeniu, że owego „najwyższego ośrodka władzy” nie należy automatycznie utożsamiać wyłącznie z ośrodkiem prezydenckim.

Do 2007 r. aktualne było stwierdzenie, że los partii władzy zależał od poparcia ze strony ośrodka prezydenckiego ${ }^{20}$. Natomiast w 2007 r., kiedy prezydentem Federacji Rosyjskiej został Miedwiediew, twierdzenie to straciło na aktualności. Jedna Rosja nie przestała bowiem być partią władzy, a jej siła wynikała nie z poparcia ze strony Miedwiediewa - którego przecież partia ta formalnie desygnowała jako własnego kandydata na urząd głowy państwa - tylko z popularności Putina, który objął stanowisko premiera, a także oparcia w aparacie państwowym i gospodarczym państwa. Bardziej adekwatne jest więc stwierdzenie, że rosyjskie partie władzy funkcjonują "na styku administracji państwa i polityki”, korzystając przy tym ze środków znajdujących się w dyspozycji państwa ${ }^{21}$.

Warta podkreślenia jest również inna cecha partii władzy, której badacze jak dotąd nie wyeksponowali. Wydaje się, że jednym z podstawowych zadań partii władzy

16 Zob. szerzej: A. Skrzypek, Druga smuta. Zarys dziejów Rosji 1985-2004, Warszawa 2004, s. 100-102.

17 R. Bäcker, op. cit., s. 44.

18 Program wyborczy partii Jedna Rosja z 2011 r. zob. http://er.ru/party/program/, inf. 20 VI 2014.

19 Więcej o partiach typu catch-all zob. np. W. Sokół, M. Żmigrodzki, Wspótczesne partie i systemy partyjne. Zagadnienia teorii i praktyki politycznej, Lublin 2003, s. 31.

20 J. Potulski, System partyjny Rosji..., s. 269.

21 Ibidem. 
jest zapewnienie ciągłości funkcjonowania elit państwowych, nawet jeżeli procesowi temu towarzyszy kontrolowana wymiana ludzi władzy. Świadczy o tym podstawowy cel, dla którego powstawały kolejne partie władzy - Wybór Rosji miał za zadanie zapewnić parlamentarne poparcie dla prezydenta Jelcyna oraz dla programu transformacji ustrojowo-gospodarczej, którego twarzą stał się wówczas premier Jegor Gajdar ${ }^{22}$. Z kolei ugrupowanie Nasz Dom - Rosja powstało w wyniku rozłamu w obozie reformatorskim, a podstawową przesłanką powstania tej partii było zapewnienie poparcia dla frakcji opowiadającej się za mniej drastycznym programem reform ${ }^{23}$. Natomiast Jedna Rosja została utworzona na potrzeby Putina z połączenia istniejących już partii Jedność (założonej przez oligarchę 24 Borysa Berezowskiego) i Ojczyzna - Cała Rosja (utworzonej przez ówczesnego mera Moskwy Jurija Łużkowa). Mocodawcy tej partii podobnie jak odchodzący prezydent Jelcyn - planowali za jej pośrednictwem zachować swoje wpływy w obozie kremlowskim ${ }^{25}$. Natomiast formalne desygnowanie Miedwiediewa przez Jedną Rosję na kandydata na urząd prezydenta miało służyć zachowaniu wpływów przez ówczesny establishment polityczny i partyjny.

Powyższe wywody prowadzą do konkluzji, że do najważniejszych cech charakteryzujących partie władzy należą:

1) tworzenie tych partii wokół ważnych osobistości politycznych;

2) koncentrowanie się w pierwszej kolejności na artykulacji i agregacji potrzeb i interesów własnych patronów/mocodawców lub osób $\mathrm{z}$ ich najbliższego otoczenia, a nie reprezentacji potrzeb i interesów społecznych;

3) ścisłe powiązanie partii władzy z aparatem państwowym i korzystanie ze środków znajdujących się w dyspozycji państwa;

4) dążenie partii władzy do zapewnienia ciągłości funkcjonowania elit państwowych, nawet jeśli proces ten odbywa się w drodze rekrutacji elit.

Warto też podkreślić, że nie należy utożsamiać partii władzy z partią dominującą. Pojęcie partii dominującej, choć powszechnie przyjęte, również nie zostało sprecyzowane, jednak w nauce mianem partii dominującej określa się takie ugrupowanie, które w danym państwie przez dłuższy czas dystansuje inne partie i utrzymuje się u władzy ${ }^{26}$. Nietrudno zauważyć, że problematyczne jest określenie dwóch kluczowych kryteriów pozwala-

22 E. Zieliński, op. cit., s. 101-102.

23 J. Zieliński, System partyjny współczesnej Rosji, [w:] Federacja Rosyjska 1991-2001, red. J. Adamowski, A. Skrzypek, Warszawa 2002, s. 203-204.

${ }^{24}$ Terminy „oligarchia” czy „oligarchowie” są dość powszechnie stosowane zarówno w publicystyce, jak i nauce polskiej i zagranicznej jako określenie wpływowych osobistości świata biznesu w państwach Europy Wschodniej powstałych po rozpadzie ZSRR, jednak nie znalazłem jak dotąd konkretnej definicji tego pojęcia w odniesieniu do współczesnej Federacji Rosyjskiej; w mediach oligarchowie rozumiani są na ogół jako „ludzie bardzo bogaci i mający przy tym duży wpływ na politykę”. P. Kościński, T. Serwetnyk, Spadkobiercy oligarchów, http://www.rp.pl/artykul/896791.html, inf. 22 VI 2014; C. Ericson, Oligarchowie. Pieniądze i władza w kapitalistycznej Rosji, Warszawa 2014, passim.

25 Zob. szerzej: T. Bichta, M. Kowalska, W. Sokól, System polityczny Rosji, [w:] Systemy polityczne państw Europy Środkowej i Wschodniej, red. W. Sokół, M. Żmigrodzki, Lublin 2005, s. 401.

26 G. Satori, Parties and Party Systems: A Framework for Analysis, Colchester 2005, s. 171. 
jących na wyodrębnienie partii dominującej - czasu, przez który dana partia musi dystansować swoich rywali, a także rozmiaru przewagi nad najgroźniejszym konkurentem. Badacze próbowali wprawdzie konkretyzować drugi z tych parametrów, jednak doszli oni do odmiennych wniosków - Giovanni Sartori założył, że o partii dominującej można mówić już wtedy, gdy przewaga zwycięskiego ugrupowania nad drugą partią w kolejnych wyborach wynosi co najmniej $10 \%{ }^{27}$, natomiast krytycy tej koncepcji proponowali, żeby tym mianem określać partie, które dysponują bezwzględną większością miejsc w parlamencie ${ }^{28}$. Na potrzeby niniejszego opracowania za wystarczający wyznacznik partii dominującej przyjęto korzystniejszą dla ugrupowań politycznych proponowaną przez Sartoriego dziesięcioprocentową przewagę partii zwycięskiej nad najgroźniejszym rywalem oraz utrzymywanie się partii u władzy przez dłużej niż dwie kadencje. W odpowiedzi na pytanie, czy rosyjskie partie władzy można zaliczyć do partii dominujących, pomocna będzie tabela 1, przedstawiająca rezultaty osiągnięte przez partie władzy w wyborach do Dumy Państwowej - niższej izby rosyjskiego parlamentu - na tle innych ugrupowań. Za miarodajny wskaźnik w okresie funkcjonowania w Rosji mieszanego systemu wyborczego przyjęto wyniki uzyskane $\mathrm{w}$ segmencie proporcjonalnym (w okresie funkcjonowania mieszanego systemu wyborczego w głosowaniu na listy partyjne ${ }^{29}$.

Tabela 1. Rezultaty uzyskane przez partie władzy w wyborach do Dumy Państwowej w latach 1993-2011 na tle pozostałych ugrupowań politycznych

\begin{tabular}{|c|l|c|c|c|}
\hline Wybory & \multicolumn{1}{|c|}{ Nazwa partii } & $\begin{array}{c}\text { Miejsce w wyborach } \\
\text { (segment proporcjonalny) }\end{array}$ & $\begin{array}{c}\text { Wynik } \\
\text { wyborczy }\end{array}$ & $\begin{array}{c}\text { Przewaga nad } \\
\text { drugą partią }\end{array}$ \\
\hline 1993 & Wybór Rosji & 2. & $15,5 \%$ & - \\
\hline 1995 & Nasz Dom - Rosja & 3. & $10,1 \%$ & - \\
\hline 1999 & Jedność (Niedźwiedź) & 2. & $23,2 \%$ & - \\
\hline 1999 & Ojczyzna - Cała Rosja & 3. & $12,1 \%$ & - \\
\hline 1999 & Nasz Dom - Rosja & 10. & $1,2 \%$ & - \\
\hline 2003 & Jedna Rosja & 1. & $37,6 \%$ & $25,0 \%$ \\
\hline 2007 & Jedna Rosja & 1. & $64,3 \%$ & $52,7 \%$ \\
\hline 2011 & Jedna Rosja & 1. & $49,4 \%$ & $30,2 \%$ \\
\hline 2016 & Jedna Rosja & 1. & $54,2 \%$ & $40,9 \%$ \\
\hline
\end{tabular}

Źródło: Opracowanie własne na podstawie www.parties-and-elections.eu

Analiza tabeli 1 pozwala na stwierdzenie, że z dotychczas istniejących rosyjskich partii władzy tylko Jedna Rosja może uchodzić za partię dominującą. Ugrupowanie stworzone na potrzeby Putina wyraźnie zdominowało bowiem największych konku-

27 Ibidem.

28 A. Antoszewski, Partia dominująca, [w:] Encyklopedia politologii, t. 3: Partie i systemy partyjne, red. A. Antoszewski, R. Herbut, Kraków 1999, s. 131.

$29 \mathrm{~W}$ tabeli 1 przedstawiono wyniki oddane wyłącznie na listy partyjne, bez uwzględniania mandatów uzyskanych przez członków partii wybranych w okręgach jednomandatowych (do 2007 r. obowiązywał w Rosji mieszany system wyborczy, o czym będzie mowa w dalszej części pracy) ani kandydatów, którzy startowali w wyborach jako kandydaci niezależni. 
rentów - od 2003 r. Jedna Rosja niepodzielnie panuje na rosyjskiej scenie politycznej, a przewaga tego ugrupowania nad kolejnym podmiotem wyborczym jest nie mniejsza niż 25\%. Natomiast istniejących wcześniej partii władzy w żadnym razie nie można zaliczyć do podmiotów dominujących, ponieważ żadna z nich nie odniosła zwycięstwa $\mathrm{w}$ wyborach proporcjonalnych. Wprawdzie partie te uzyskały najwięcej miejsc w Dumie Państwowej, ale wynikało to głównie z mieszanego systemu wyborczego i dużej liczby głosów oddanych przez wyborców na kandydatów tych ugrupowań w okręgach jednomandatowych, a także z faktu, że duża liczba deputowanych startujących jako niezależni zasilała w trakcie kadencji Dumy szeregi frakcji parlamentarnych partii władzy. Widać więc, że nie każda partia władzy spełniała wskazane przez G. Sartoriego kryteria partii dominującej.

\section{Determinanty funkcjonowania partii władzy w Federacji Rosyjskiej}

Niezmiernie ważnym zagadnieniem w analizie partii władzy jest ustalenie czynników, dzięki którym tego typu ugrupowania mogły zaistnieć na rosyjskiej scenie politycznej. Do kluczowych determinantów funkcjonowania partii władzy w Federacji Rosyjskiej należy zatem zaliczyć:

1) determinanty prawne, $w$ tym konstytucyjne uprzywilejowanie władzy wykonawczej kosztem władzy ustawodawczej w rosyjskim systemie politycznym, przepisy ustawy federalnej o partiach politycznych, m.in. zasady rejestracji, konieczność startu w wyborach pod groźbą likwidacji partii oraz system wyborczy;

2) determinanty polityczne, m.in. sieć powiązań pomiędzy administracją federalną a oligarchią, kluczowymi gałęziami przemysłu i służbami specjalnymi oraz upolitycznienie mediów państwowych i Centralnej Komisji Wyborczej;

3) determinanty historyczne, m.in. słabe tradycje demokratyczne i parlamentarne na ziemiach rosyjskich oraz fakt, że w pierwszej kolejności w Federacji Rosyjskiej odbyły się wybory prezydenckie, a dopiero po dwóch latach przeprowadzono wybory parlamentarne.

Niewątpliwie do najważniejszych determinantów funkcjonowania rosyjskich partii władzy należą determinanty prawne. Najważniejsze z nich są związane z kształtem systemu rządów Federacji Rosyjskiej, usytuowaniem partii politycznych w rosyjskim systemie prawnym, a także - po części - z systemem wyborczym Rosji.

Cechą wyróżniającą rosyjskiego systemu politycznego jest silna pozycja ustrojowa prezydenta i podrzędna rola parlamentu w stosunku do władzy wykonawczej ${ }^{30}$. Nie wdając się w szczegółową analizę kompetencji poszczególnych organów władzy w Rosji, warto zwrócić uwagę na kluczowy dla określenia relacji między legislatywą a egzekutywą - a także miejsca partii politycznych w rosyjskim systemie politycznym - mechanizm rozwiązania Dumy Państwowej. Zgodnie z Konstytucją Federacji Rosyjskiej Duma Państwowa może zostać rozwiązana w przypadku:

30 Zob. szerzej: O. Krysztanowskaja, op. cit., s. 76-78; A. Bosiacki, H. Izdebski, Konstytucjonalizm rosyjski. Historia i współczesność, Kraków 2013, s. 306-309. 
1) trzykrotnego odrzucenia przez Dumę przedstawionych przez prezydenta kandydatur na stanowisko premiera (w takiej sytuacji prezydent wybiera nowego Przewodniczącego Rządu, rozwiązuje Dumę i zarządza nowe wybory) ${ }^{31}$;

2) dwukrotnego udzielenia w ciągu trzech miesięcy wotum nieufności Rządowi Federacji Rosyjskiej (prezydent może wtedy zdymisjonować rząd lub rozwiązać Dumę) ${ }^{32}$;

3) odmowy udzielenia wotum zaufania rządowi (w tym przypadku prezydent również ma możliwość zdymisjonowania rządu lub rozwiązania Dumy ${ }^{33}$.

Takie rozwiązania ustrojowe powodują, że niższa izba parlamentu rosyjskiego jest de facto pozbawiona możliwości sprawowania funkcji kontrolnej wobec rządu, ponieważ każda forma wyrażenia wotum nieufności wobec władzy wykonawczej może być dla Dumy równoznaczna z jej rozwiązaniem. Słaba pozycja parlamentu w systemie naczelnych organów władzy Rosji ma także duże znaczenie dla partii politycznych, dla których parlament jest podstawowym polem aktywności politycznej. Przedstawione mechanizmy ustrojowe, które grożą Dumie Państwowej rozwiązaniem przez prezydenta w przypadku prób rozliczenia egzekutywy, powodują, że ugrupowania polityczne, chcąc dotrwać w niższej izbie parlamentu do końca kadencji, są zmuszone do zachowań politycznych submisyjnych wobec ośrodka prezydenckiego i rządowego. Nic więc dziwnego, że taka sytuacja ustrojowo-polityczna w Rosji sprzyjała powstawaniu partii władzy, które nie dość, że były uzależnione od swoich mocodawców funkcjonujących już w rosyjskim aparacie państwowym, to predestynowano je do posłuszeństwa wobec władzy wykonawczej.

Istnieniu partii władzy sprzyjały również niektóre przepisy ustawy federalnej o partiach politycznych z 11 lipca $2001 \mathrm{r}$. Najważniejszy z nich dotyczył formalnych warunków zarejestrowania organizacji społecznej jako partii politycznej. Zgodnie $\mathrm{z}$ art. 3 ustawy jako partie polityczne mogły być zarejestrowane te organizacje, które posiadały oddziały regionalne przynajmniej w połowie podmiotów Federacji Rosyjskiej, przy czym w jednym podmiocie może istnieć tylko jeden oddział regionalny ${ }^{34}$. Natomiast liczba członków koniecznych do zarejestrowania organizacji jako partii politycznej w Rosji systematycznie ograniczano - w pierwotnym kształcie ustawa określała tę liczbę na 10 tys., a w myśl nowelizacji z 2012 r. do rejestracji partii wystarczy 500 członków ${ }^{35}$. Liberalizacje dotyczące liczby członków niezbędnych do zarejestrowania partii politycznych nie zmieniają jednak faktu, że przedstawione powyżej rozwiązania ustawowe powodują, że w Rosji status partii politycznej mogą zyskać tylko organizacje duże, mające szanse na stworzenie ogólnokrajowej struktury, co z kolei jest znacznie łatwiejsze, jeżeli dana organizacja może swobodnie korzystać ze środków pozostających $\mathrm{w}$ dyspozycji aparatu państwa. Trudno zaakceptować uzasadnienie, że

31 Art. 111 ust. 4 Konstytucji.

32 Art. 117 ust. 3 Konstytucji.

33 Art. 117 ust. 4 Konstytucji.

34 Art. 3 ust. 2 Ustawy federalnej o partiach politycznych z 11 lipca 2001 roku (dalej: Ustawy o partiach).

35 Należy zauważyć, że niezbyt wysoki próg liczby członków może sprzyjać tworzeniu kolejnych partii politycznych, co w efekcie prowadzi do fragmentaryzacji opozycyjnej części sceny partyjnej. 
w konsekwencji takiego wysokiego progu instytucjonalizacji prawnej partiami politycznymi mogą być wyłącznie organizacje dające podstawy poważnej realizacji swoich celów ${ }^{36}$. Taka weryfikacja powinna bowiem zachodzić na etapie wyborów, a nie rejestrowania partii. Obowiązujące przepisy już w fazie rejestracji dają zatem przewagę partiom władzy.

Kolejnym przepisem ustawy federalnej o partiach politycznych sprzyjającym partiom władzy jest ustawowy obowiązek startu w wyborach pod groźbą likwidacji. W pierwotnej redakcji ustawy likwidacji z mocy prawa podlegała partia, która nie weźmie udziału w jakichkolwiek wyborach - o zasięgu federalnym lub lokalnym - przynajmniej raz w ciągu pięciu lat, a w 2012 r. okres ten został wydłużony do siedmiu lat ${ }^{37}$. Wydawać by się mogło, że taki przepis zachęca partie do aktywności politycznej, jednak rozwiązanie to niesie za sobą także pewne niebezpieczeństwo, ponieważ wystarczy, że Centralna Komisja Wyborcza odmówi rejestracji listy kandydatów danego ugrupowania, a partia ta ulegnie likwidacji. Obserwowana praktyka polityczna pokazuje, że odmowa rejestracji list kandydatów ugrupowań - zwłaszcza opozycyjnych wobec obozu władzy - była przez CKW stosowana niemal przed wszystkimi dotychczasowymi elekcjami parlamentarnymi ${ }^{38}$. Partiom władzy niedopuszczenie do udziału w wyborach raczej nie grozi, ponieważ Centralna Komisja Wyborcza jest instytucją wyraźnie upolitycznioną - składa się z 15 członków, z których pięciu jest wyznaczonych przez prezydenta, a pozostali są wybierani przez Dumę Państwową i Radę Federacji.

Czynnikiem systemowym do pewnego stopnia sprzyjającym istnieniu partii władzy w Rosji jest także system wyborczy. Do 2007 r. w Rosji obowiązywała ordynacja wyborcza, w myśl której połowa z 450 posłów do Dumy była wybierana w jednomandatowych okręgach wyborczych, a druga połowa pochodziła z głosowania na listy partyjne w systemie proporcjonalnym (tzw. system list partyjnych zamkniętych), przy czym w podziale mandatów brały udział te partie, które w skali kraju uzyskały 5\% głosów ${ }^{39}$. O tym, że partie władzy stały się beneficjentem takiego rozwiązania, świadczy

36 J. Potulski, System partyjny Rosji..., s. 232.

37 Art. 37 ust. 2 Ustawy o partiach.

38 E. Zieliński, op. cit., s. 99-100.

39 Mieszany system wyborczy został wprowadzony Dekretem Prezydenta Federacji Rosyjskiej z 21 września 1993 r. w okresie walki, jaką prezydent Jelcyn prowadził z Dumą Państwową. Można więc powiedzieć, że takie rozwiązanie zostało narzucone przez Jelcyna. U podstaw takiej decyzji leżały przede wszystkim trzy powody: 1) możliwość zniwelowania wysokiego poziomu niepewności co do rezultatów wyborów, które niosłoby za sobą wprowadzenie systemu proporcjonalnego lub większościowego, 2) próba wykreowania przez ówczesny obóz prezydencki systemu umiarkowanie wielopartyjnego, 3) stosunkowo łatwe uzyskanie legitymizacji wprowadzonych rozwiązań, ponieważ mieszany system wyborczy miał być w opinii Kremla odbierany jako próba pogodzenia sprzecznych interesów różnych sił politycznych, a także jako „postępowy”, ponieważ podobne rozwiązania ustrojowe przyjmowały w tamtym czasie m.in. Włochy, Japonia czy Nowa Zelandia. W. Sokół, Geneza i ewolucja systemów wyborczych w państwach Europy Środkowej i Wschodniej, Lublin 2007, s. $551,576-577$. 
porównanie ilości mandatów uzyskanych przez te ugrupowania w głosowaniu na listy partyjne i w jednomandatowych okręgach wyborczych, co przedstawia tabela 2.

Tabela 2. Porównanie liczby mandatów uzyskanych przez partie władzy w głosowaniu na listy partyjne i w jednomandatowych okręgach wyborczych

\begin{tabular}{|c|l|c|c|}
\hline Wybory & Nazwa partii & $\begin{array}{c}\text { Ilość mandatów uzyskanych } \\
\text { w głosowaniu na listy partyjne } \\
(\mathrm{PR})\end{array}$ & $\begin{array}{c}\text { Ilość mandatów uzyskanych } \\
\text { w jednomandatowych } \\
\text { okręgach wyborczych }\end{array}$ \\
\hline 1993 & Wybór Rosji & 40 & 30 \\
\hline 1995 & Nasz Dom - Rosja & 45 & 10 \\
\hline 1999 & Jedność (Niedźwiedź) & 64 & 9 \\
\hline 1999 & Ojczyzna - Cała Rosja & 37 & 31 \\
\hline 2003 & Jedna Rosja & 120 & 102 \\
\hline 2007 & Jedna Rosja & 315 & - \\
\hline 2011 & Jedna Rosja & 238 & 203 \\
\hline 2016 & Jedna Rosja & 140 & - \\
\hline
\end{tabular}

Źródło: opracowanie własne na podstawie: http://www.russiavotes.org

Widać zatem, że mieszany system wyborczy na ogół był korzystnym rozwiązaniem dla partii władzy. Dzięki mandatom zdobytym w jednomandatowych okręgach wyborczych Wybór Rosji, Ojczyzna - Cała Rosja i Jedna Rosja niemal podwoiły swój stan posiadania w Dumie Państwowej. Jednak - jak pokazuje przykład ugrupowania Nasz Dom - Rosja - nie było to regułą. Z kolei ugrupowanie Jedność samodzielnie w jednomandatowych okręgach wyborczych osiągnęło bardzo słaby wynik, ale jeśli potraktujemy tę partię i Ojczyznę - Całą Rosję jako dwa ugrupowania tego samego obozu władzy (a stanowisko takie uważam za uzasadnione, ponieważ w 2001 roku obie partie weszły w skład nowo powstałej Jednej Rosji $)^{40}$, to wynik wyborczy tego „obozu” uzyskany w jednomandatowych okręgach wyborczych będzie dużo lepszy. Warto natomiast podkreślić, że choć mandaty uzyskane w głosowaniu większościowym niejednokrotnie znacznie polepszyły wynik wyborczy partii władzy, to jednak podstawą sukcesu wyborczego tych ugrupowań był dobry rezultat uzyskany w głosowaniu proporcjonalnym. Świadczy o tym fakt, że po reformie ordynacji wyborczej i wprowadzeniu systemu proporcjonalnego w wyborach do Dumy ${ }^{41}$ Jedna Rosja osiągnęła najlepsze wyniki wyborcze w dziejach rosyjskich partii władzy (dla przypomnienia w 2007 r. partia ta osiągnęła 64,3\% poparcia, a w 2011 r. - 49,4\%). Z kolei w elekcji parlamentarnej 2016 r. przeprowadzonej w warunkach przywróconego mieszanego systemu wyborczego Jedna Rosja osiągnęła przygniatającą przewagę nad konkurentami, zarówno w segmencie

40 Zob. szerzej: K. Świder, op. cit., s. 260-261.

${ }^{41}$ Od wyborów parlamentarnych z 2007 r. w Rosji obowiązuje proporcjonalny system wyborczy, a w podziale mandatów biorą udział te listy partyjne, które w skali Federacji uzyskały co najmniej 7\% poparcia. W. Sokół, Geneza i ewolucja..., s. 565. 
większościowym, jak i proporcjonalnym. Zatem polityka reform systemów wyborczych sprzyjała wzrostowi potencjału politycznego partii władzy.

Wśród zjawisk, które przyczyniły się do powstania partii władzy, wskazuje się także determinanty polityczne. Należy do nich przede wszystkim cienka granica pomiędzy sferą polityki a aparatem państwowym w Rosji ${ }^{42}$. O tym, że partie władzy są beneficjentem również takiej sytuacji, świadczy możliwość korzystania z zasobów administracyjnych państwa. To ostatnie pojęcie doprecyzował J. Ćwiek-Karpowicz, który przez wykorzystanie „administracyjnych zasobów” rozumie „różną formę (od legalnej, półlegalnej i jawnie bezprawnej - np. falsyfikacji wyników) wykorzystania administracji wszelkiego szczebla do celów partii", przy czym szczególnie istotne dla partii są zasoby władzy wykonawczej ${ }^{43}$. Jak wcześniej wspomniano, korzyści płynące z powiązań partii władzy z aparatem biurokratycznym Rosji są dla tych ugrupowań widoczne już na etapie powstania i rejestracji partii. W czasie kampanii wyborczej pośrednim przejawem korzystania przez partie władzy $\mathrm{z}$ aparatu administracyjnego państwa jest nadmierne wykorzystywanie upolitycznionych państwowych mediów do promowania własnych osiągnięć. I tak, z raportu Organizacji Bezpieczeństwa i Współpracy w Europie dotyczącego wyborów parlamentarnych z 2011 r. wynika, że państwowe stacje telewizyjne - zobligowane prawem do poświęcania różnym opcjom politycznym równego czasu antenowego - znacznie częściej prezentowały spoty wyborcze Jednej Rosji ${ }^{44}$.

Nie miała znaczenia dla potencjału partii władzy kwestia afiliacji partyjnej prezydenta. W 1991, 1996, 2004 czy 2018 Borys Jelcyn i Władimir Putin startowali w wyborach jako kandydaci bezpartyjni, chociaż za każdym razem ich kandydatura bazowała na poparciu określonych partii politycznych (w przypadku Jelcyna były to Demokratyczna Rosja w 1991 r. i Nasz Dom - Rosja w 1996 r., natomiast kandydaturę W. Putina zawsze popierała Jedna Rosja, niezależnie od braku formalnej afiliacji tych przywódców politycznych) ${ }^{45}$.

Warto także zwrócić uwagę na inne zjawiska polityczne, które sprzyjały powstaniu partii władzy. Pierwszym $z$ nich jest kolejność wyboru nowych rosyjskich organów władzy - pierwsze wybory prezydenckie w Rosji odbyły się 12 czerwca $1991 \mathrm{r}$., a pierwsze wybory do Zgromadzenia Federalnego przeprowadzono 12 grudnia 1993 r. Ponadto inna kluczowa postać w procesie transformacji ustrojowej w Rosji, Jegor Gajdar, od 1991 r. był wicepremierem i ministrem finansów, a od 1992 r. pełnił obowiązki premiera ${ }^{46}$. Widać więc, że Jelcyn i Gajdar, wokół których powstała pierwsza partia władzy Wybór Rosji, funkcjonowali w nowo powstającym rosyjskim aparacie państwowym dwa lata przed pierwszymi wyborami parlamentarnymi w Rosji, dzięki czemu

42 J. Potulski, System partyjny Rosji..., s. 269.

43 J. Ćwiek-Karpowicz, op. cit., s. 58.

44 A. Szymańska, Demokracja po rosyjsku, http://notabene.org.pl/index.php/demokracja-po-rosyjsku/, inf. 22 VI 2014.

45 Więcej o kandydatach w kolejnych wyborach prezydenckich w Rosji zob. http://polish.ruvr. $\mathrm{ru} / 2012 / 01 / 12 / 63707419 . \mathrm{html}$, inf. 22 VI 2014.

46 W. Sorgin, op. cit, s. 205-206. 
elity władzy miały dość dużo czasu na stworzenie odpowiadających im ugrupowań politycznych. Gdyby wybory odbywały się w odwrotnej kolejności lub w podobnym czasie, przedstawiciele władzy wykonawczej mieliby mniejsze szanse na doprowadzenie do takiej sytuacji. Drugim z tych zjawisk jest ścisłe powiązanie między administracją państwową a oligarchią, przedstawicielami przemysłu (zwłaszcza energetycznego) i służbami specjalnymi. Nie pozostaje to bez wpływu na istnienie partii władzy, o czym świadczy chociażby fakt, że lider ugrupowania Nasz Dom - Rosja premier Wiktor Czernomyrdin w latach 1989-1992 był szefem potężnego państwowego koncernu Gazprom, największego wydobywcy gazu ziemnego na świecie ${ }^{47}$. W tworzeniu ugrupowania Jedność kluczową rolę odegrał czołowy oligarcha lat 90. XX w. Borys Berezowski. Natomiast najlepszym dowodem na związki rosyjskich elit politycznych ze służbami specjalnymi jest sam W. Putin, który nigdy nie ukrywał, że w latach 70. i 80. XX w. był funkcjonariuszem Komitetu Bezpieczeństwa Wewnętrznego (KGB) ${ }^{48}$. Dowodzi to faktu, że dzięki powiązaniom $\mathrm{z}$ aparatem państwowym przez partie władzy oligarchowie oraz przedstawiciele dużych koncernów państwowych i służb specjalnych mogą w dość prosty sposób wpływać m.in. na proces legislacyjny.

Do czynników sprzyjających - choć nie bezpośrednio - istnieniu partii władzy w Federacji Rosyjskiej można zaliczyć również czynniki historyczno-kulturowe, do których należy tradycja silnej władzy w Rosji i dość rachityczne tradycje parlamentarne. Od czasów średniowiecza panował w Rosji ustrój patrymonialny ${ }^{49}$ pod różnymi postaciami (despotyzm, absolutyzm oświecony, samodzierżawie), który wraz z dojściem do władzy bolszewików w 1917 r. przekształcił się w reżim totalitarny ${ }^{50}$. Dominująca pozycja władcy (księcia, chana, cara czy pierwszego sekretarza partii komunistycznej) w rosyjskim systemie organów władzy niemal przez całą historię państwa rosyjskiego szła $\mathrm{w}$ parze $\mathrm{z}$ ograniczeniem roli instytucji przedstawicielskich $\mathrm{w}$ procesie decyzyjnym. Z wyjątkiem Soboru Ziemskiego, który stał się wzorem dla późniejszej Dumy Państwowej, ogólnopaństwowe instytucje przedstawicielskie w Rosji carskiej Duma Bojarska i Senat Rządzący - były zależne od cara, który posiadał władzę niemal absolutną ${ }^{51}$. Zbyt krótki był okres monarchii konstytucyjnej po 1906 r. i republiki demokratycznej po rewolucji lutowej, aby w rosyjskiej tradycji i kulturze politycznej utrwaliły się wartości i procedury konieczne dla implementacji pluralizmu politycznego. W czasach funkcjonowania reżimu totalitarnego cechą konstytutywną RSFRR i ZSRR była także monopartyjność - jedyną legalną partią była partia komunistyczna

47 A. Furier, Dekada Jelcyna. Uwarunkowania rosyjskich przemian społecznych i politycznych 1991-2000, Szczecin 2003, s. 255-256; A. Skrzypek, op. cit., s. 115-116.

48 A. Grajewski, Tarcza i miecz. Rosyjskie stużby specjalne 1991-1998, Warszawa 1998, s. 326-329; T. Osuch, Putin. Od KGB przez Czeczenię - droga do władzy, http://www.wiadomosci24.pl/artykul/ putin_od_kgb_przez_czeczenie_droga_do_wladzy_155476.html, inf. 23 VI 2014.

49 Szczegółową analizę ustroju patrymonialnego w Rosji przedstawił R. Pipes, Rosja carów, Warszawa 2006, s. 59-114.

50 J. Potulski, Rola i znaczenie tradycji..., s. 175-176.

51 A. Bosiacki, H. Izdebski, op. cit., s. 21-53. 
(pod różnymi nazwami), a sekretarz generalny Komitetu Centralnego partii spełniał de facto rolę dyktatora ${ }^{52}$. Wydaje się, że silna pozycja prezydenta Federacji Rosyjskiej i mniejsze znaczenie Zgromadzenia Federalnego we współczesnym rosyjskim systemie politycznym jest również konsekwencją rosyjskiej tradycji politycznej. Pośrednio tłumaczy to więc także istnienie w Rosji partii władzy, ponieważ z racji wielowiekowego upośledzenia ciał przedstawicielskich w rosyjskim systemie politycznym nie było kulturowych wzorców dla rozwoju rywalizacyjnego systemu partyjnego typowego dla demokracji zachodnich. Znacznie łatwiej znaleźć w historii politycznej Rosji odniesienia dla współczesnych partii władzy, opartych na relacjach ze swoimi wpływowymi patronami ${ }^{33}$.

Reasumując, należy podkreślić, że partie władzy powstawały na potrzeby lidera politycznego lub grupy osób powiązanych z funkcjonującym aparatem państwowym, którego nadrzędnym celem jest zapewnienie poparcia parlamentarnego swoim mocodawcom lub osobom z ich najbliższego otoczenia. Partie władzy w Rosji wpisały się w system polityczny tego państwa. Funkcjonowanie tych partii poważnie ogranicza możliwości rozwoju pluralizmu politycznego i rywalizacji wyborczej. Funkcje partii władzy, począwszy od lat 90 . XX w., koncentrowały się wokół rekrutacji elit politycznych. Na tle ugrupowań z okresu prezydentury B. Jelcyna Jedna Rosja wygrywa kolejne wybory, wykazuje spójność wewnętrzną, maksymalizuje swoje zasoby i potencjał polityczny. Jedna Rosja kontroluje proces legislacyjny, obsadza większość urzędów publicznych, wyznacza przewodniczącego partii, który obejmuje funkcje premiera.

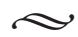

Streszczenie: Partie władzy powstały na potrzeby lidera politycznego lub grupy ludzi związanych z funkcjonującym aparatem państwowym. Nadrzędnym celem partii władzy jest instytucjonalizacja zaplecza politycznego obozu rządzącego. Partie władzy w Rosji stały się częścią systemu politycznego tego państwa. Funkcjonowanie tych partii poważnie ogranicza możliwości rozwoju pluralizmu politycznego i rywalizacji wyborczej. Funkcje partii rządzącej od lat 90 . XX wieku skupiały się na rekrutacji elit politycznych. Partia władzy Jedna Rosja wygrywa obecnie kolejne wybory, wykazuje wewnętrzną

52 Ibidem, passim; do 1918 r. partia komunistyczna nosiła nazwę Socjaldemokratyczna Partia Robotnicza (bolszewików) - SDPRR(b), w tym samym roku zmieniła nazwę na Rosyjską Komunistyczną Partię (bolszewików) - WKP(b), następnie w 1925 r. przemianowała się na Wszechrosyjską Komunistyczną Partię (bolszewików), by od XIX Zjazdu partii w 1952 r. funkcjonować jako Komunistyczna Partia Związku Radzieckiego. Pod tą nazwą partia przetrwała do 1991 r., kiedy prezydent Jelcyn wydał dekret o likwidacji KPZR. W. Marciniak, op. cit., s. 150.

53 Wpływ braku tradycji demokratycznych na kształt obecnego rosyjskiego systemu politycznego zakwestionował Adam R. Bartnicki, który stwierdził, że istnieją państwa, które pomimo braku tradycji demokratycznych doskonale odnalazły się w reżimie demokratycznym - np. Japonia i Niemcy. A.R. Bartnicki, op. cit., s. 43. 
Pobrane z czasopisma Wschód Europy http://journals.umcs.pl/we

Data: 26/04/2023 14:26:03

Pojęcie, specyfika i uwarunkowania partii władzy w Federacji Rosyjskiej

spójność, maksymalizuje swoje zasoby i potencjał polityczny. Partia władzy kontroluje proces legislacyjny i skutecznie wpływa na politykę państwa.

Słowa kluczowe: Federacja Rosyjska, partie władzy, Jedna Rosja.

\title{
Понятие, специфика и условия партии власти в Российской Федерации
}

Аннотация: Партии власти возникли для нужд политического лидера или группы людей, связанных с функционирующим государственным аппаратом, главной целью которого является оказание парламентской поддержки своим руководителям или людям из их непосредственного окружения. Партии власти в России стали частью политической системы этого государства. Функционирование этих партий серьезно ограничивает возможности развития политического плюрализма и соперничества на выборах. Функции правящей партии с 1990-х годов были сосредоточены на наборе политических элит. Одна Россия побеждает на следующих выборах, демонстрирует внутреннюю согласованность, максимизирует свои ресурсы и политический потенциал. Партия власти контролирует законодательный процесс и эффективно влияет на политику государства.

Ключевые слова: Российская Федерация, силовые партии, Единая Россия.

\section{The concept, specifics and conditions of the power party in the Russian Federation}

\begin{abstract}
The power parties arose for the needs of a political leader or a group of people associated with the functioning state apparatus, whose overriding goal is to provide parliamentary support to its principals or people from their immediate environment. The parties of power in Russia have become part of the political system of this state. The functioning of these parties seriously limits the possibilities of developing political pluralism and electoral rivalry. The functions of the ruling party since the 1990s have focused on the recruitment of political elites. One Russia wins the next election, shows internal coherence, maximizes its resources and political potential. The power party controls the legislative process and effectively influences the policy of the state.
\end{abstract}

Keywords: Russian Federation, power parties, United Russia.

\section{Bibliografia}

Antoszewski A., Partia dominująca, [w:] Encyklopedia politologii, t. 3: Partie i systemy partyjne, red. A. Antoszewski, R. Herbut, Kraków 1999.

Bäcker R., Rosyjskie myślenie polityczne za czasów prezydenta Putina, Toruń 2007.

Bartnicki A.R., Demokratycznie legitymizowany autorytaryzm w Rosji 1991-2004, Białystok 2007.

Bichta T., Kowalska M., Sokół W., System polityczny Rosji, [w:] Systemy polityczne państw Europy Środkowej i Wschodniej, red. W. Sokół, M. Żmigrodzki, Lublin 2005.

Bosiacki A., Izdebski H., Konstytucjonalizm rosyjski. Historia i współczesność, Kraków 2013.

Czajowski A., Demokratyzacja Rosji w latach 1987-1999, Wrocław 2001.

Ćwiek-Karpowicz J., Rosyjska wielopartyjność w latach 1993-2003 - ewolucja systemu, „Międzynarodowy Przegląd Polityczny" 2004, nr 3/4 (8/9). 
Ericson C., Oligarchowie. Pieniądze i władza w kapitalistycznej Rosji, Warszawa 2014.

Federacja Rosyjska 1991-2001, red. J. Adamowski, J. Skrzypek, Warszawa 2002.

Furier A., Dekada Jelcyna. Uwarunkowania rosyjskich przemian społecznych i politycznych 1991-2000, Szczecin 2003.

Grajewski A., Tarcza i miecz. Rosyjskie służby specjalne 1991-1998, Warszawa 1998.

Jendrysko J., Rola Jednej Rosji na rosyjskiej scenie politycznej, „Studia Politicae Universitatis Silesiesiensis" 2016, t. 17.

Konstytucja Federacji Rosyjskiej z 12 grudnia 1993 r.

Kościński P., Serwetnyk T., Spadkobiercy oligarchów, http://www.rp.pl/artykul/896791.html.

Krysztanowskaja 0., Anatomia rossijskoj elity, Moskwa 2004.

Marciniak W., Rozgrabione imperium. Upadek Związku Sowieckiego i powstanie Federacji Rosyjskiej, Kraków 2004.

Osuch T., Putin. Od KGB przez Czeczenię - droga do władzy, http://www.wiadomosci24.pl/artykul/putin_od_kgb_przez_czeczenie_droga_do_wladzy_155476.html.

Pietrzko B., Geneza i konstytucyjna pozycja urzędu prezydenta jako elementy transformacji ustrojowej w Rosji, [w:] Społeczeństwo wobec problemów transformacji i integracji, red. J. Liszka, Ustroń 2000.

Pipes R., Rosja carów, Warszawa 2006.

Potulski J., Rola i znaczenie tradycji w funkcjonowaniu wspótczesnych instytucji politycznych w Rosji, Toruń 2005.

Potulski J., System partyjny Rosji. Tradycja i współczesność, Gdańsk 2007.

Program wyborczy partii Jedna Rosja z 2011 r., zob. http://er.ru/party/program/.

Rogoża J., Wybory prezydenckie w Rosji i ich konsekwencje dla Rosji oraz otoczenia międzynarodowego, „Komentarze OSW” 2008, nr 1.

Rosja. Współczesny system polityczny, red. J.I. Matwijenko, M. Wilk, Łódź 2008.

Rozpad ZSRR i jego konsekwencje dla Europy i świata, red. A. Jach, Kraków 2011.

Satori G., Parties and Party Systems: A Framework for Analysis, Colchester 2005.

Skrzypek A., Druga smuta. Zarys dziejów Rosji 1985-2004, Warszawa 2004.

Słowikowski M., Jedna Rosja w systemie politycznym Federacji Rosyjskiej, Łódź 2018.

Sokół W., Geneza i ewolucja systemów wyborczych w państwach Europy Środkowej i Wschodniej, Lublin 2007.

Sokół W., Żmigrodzki M., Współczesne partie i systemy partyjne. Zagadnienia teorii i praktyki politycznej, Lublin 2003.

Sorgin W., Politiczeskaja istoria sowriemiennoj Rossiji, 1985 2001: ot Gorbaczewa do Putina, Moskwa 2001.

Stelmach A., Zmiana i stabilność w systemie politycznym współczesnej Rosji, Poznań 2003.

Szymańska A., Demokracja po rosyjsku, http://notabene.org.pl/index.php/demokracja-po-rosyjsku/.

Świder K., Ewolucja elity władzy w Związku Radzieckim i Rosji, Warszawa 2013.

Zieliński E., Współczesna Rosja. Studium polityczno-prawne, Warszawa 1995.

Zieliński J., System partyjny współczesnej Rosji, [w:] Federacja Rosyjska 1991-2001, red. J. Adamowski, A. Skrzypek, Warszawa 2002. 